\title{
Epidemiological Studies on Sheath Blight Disease of Rice in Chhattisgarh Plains Agroclimatic Zone of Chhattisgarh, India
}

\author{
Leena Thakur, N. Lakpale, P.K. Tiwari and Ashish Pradhan*
}

Department of Plant Pathology, College of Agriculture, IGKV, Raipur (CG) 492012, India

*Corresponding author

\begin{tabular}{|l|}
\hline K e y w or d s \\
$\begin{array}{l}\text { Epidemiology, Sheath } \\
\text { blight, Correlation, } \\
\text { Weather variables. }\end{array}$ \\
\hline Article Info \\
\hline $\begin{array}{l}\text { Accepted: } \\
\text { 12 September } 2017 \\
\text { Available Online: } \\
\text { 10 November } 2017\end{array}$
\end{tabular}

A B S T R A C T
Chhattisgarh state (a part of the eastern zone) is the most congenial for rice cultivation as well as for disease development. The rice crop is known to suffer by many biotic and abiotic stresses and among biotic stresses, diseases are pivotal one. In the present study, epidemiological aspect of sheath blight disease of rice carried out. Sheath blight disease progression and apparent infection rate ( $r$ ) were maximum during observation period from 1-15 and 16-30 October in over the four years kharif season. During this period of time, crop growth stage of test variety 'Swarna' was in maximum tillering to panicle initiation stage coincide with the Tmax range $\left(30.5-32.6^{\circ} \mathrm{C}\right)$ and $\mathrm{SSH}$ range (4.2-9.6) which favours the maximum apparent rate of infection by Rhizoctonia solani and resulted in maximum sheath blight disease progression. In all the maximum value of AUDPC calculated in first date of sowing followed by second date of sowing and least in third date of sowing during kharif 2013, 2015 and 2016. In kharif 2014, it was maximum in first date of sowing followed by third date of sowing and least in second date of sowing. Year wise correlation analysis between weather parameters and sheath blight disease severity suggest that Tmax and SSH had positive effect in the development of sheath blight disease of rice during kharif season.

\section{Introduction}

Rice is an important integral part of Indian dietary and staple food of more than 60 per cent population in India. Chhattisgarh state, famous as "Rice bowl" of India, rice occupies an area of 3.7 million hectare with a production of 7.7 million metric tonnes (Anon., 2017). This state is very rich in rice germplasm and large number of indigenous collection is still maintained by the tribal farmers of the state. However, the productivity of rice in the state is much lower than national average productivity level. Chhattisgarh state (a part of the eastern zone) is the most congenial for rice cultivation as well as for disease development. The rice crop is known to suffer by many biotic and abiotic stresses and among biotic stresses, diseases are pivotal one. Among the diseases, bacterial blight, sheath blight, blast, sheath rot and false smut are the most important for this region causing economic yield losses. The rice diseases attack all the growth stages of the plant right from the nursery till the harvest of the crop.

Intensive methods of rice cultivation involving early season culture, double cropping, use of high doses of nitrogenous 
fertilizer, dense plant population per unit area and growing early maturity, short culmed, high tillering and compact susceptible cultivars have intensified the severity of the disease in all the rice growing countries. The yield loss due to sheath blight was maximum when infection started 60 days after sowing (tillering stage) and continues to subsequent booting stage (Tsai, 1974). Under favourable conditions like low sunlight, high humidity $(\geq$ $95 \%)$ and warm temperature $\left(28-32^{\circ} \mathrm{C}\right)$, the infection spreads rapidly by means of runner hyphae to upper plant parts. Lesions may coalesce to encompass the entire leaf sheath and stem (Rush and Lee, 1992).

Abnormalities produced in plants by entities are aggravated by the abiotic factors i.e. environmental conditions. Such interaction is described by classic disease triangle in which two biotic factors i.e. susceptible host and virulent pathogens and an abiotic factor i.e. environmental factor play an important role in exhalation of disease in plant in time and space. Environmental factor like temperature (minimum and maximum), relative humidity (morning and evening), rainfall and sunshine hours greatly influence the plant disease in various hosts - pathogen interactions. These factors directly or indirectly favour the growth of host plants and pathogen population to build- up and subsequently cause disease (s) in host plant to great extent resulting in economic yield losses.

In the present study, attempt was made to find out the congenial period for sheath blight disease progression in different dates of sowing and its relation with various weather variables.

\section{Materials and Methods}

The previous three years kharif season data (2013-2015) on sheath blight disease severity were obtain from the AICRP on rice, IGKV,
Raipur. Rice cultivar 'Swarna' was sown in $1 \times 10 \mathrm{~m}$ plot size with three staggering dates from $1^{\text {st }}$ June to $1^{\text {st }}$ August, 2016 with one month intervals. Disease development in terms of disease severity of sheath blight and bacterial blight was recorded at fortnightly intervals on 50 randomly selected and tagged plants in each replication and date of sowing starting from first appearance of disease symptoms.

\section{Calculation of disease severity}

It is the measure of sickness of diseased plant. It is a quantitative, which measures amount of disease on a plant in terms of intensity of symptoms or damage. Disease severity (DS) can be calculated by using formula-

Disease severity $(\%)=\frac{\text { Area of plant tissues affected }}{\text { Total area }} \times 100$

\section{Calculation of apparent infection rate $(r)$}

Apparent infection rate is the increase and decrease in disease per unit time. Vanderplank (1963) derived following formula for calculation of infection rate-

$\mathrm{r}=\frac{1}{\mathrm{t}_{2}-\mathrm{t}_{1}} \log e \frac{x_{2}\left(1-x_{1}\right)}{x_{1}\left(1-x_{2}\right)}$

Where-

$\mathrm{r}=$ apparent infection rate/ unit/ day

$\mathrm{t}_{1}=$ first date for recording disease severity

$\mathrm{t}_{2}=$ second date for recording disease severity

$\mathrm{x}_{1}=$ disease severity at time $\mathrm{t}_{1}$

$\mathrm{x}_{2}=$ disease severity at time $\mathrm{t}_{2}$

\section{Calculation of AUDPC}

The area under disease progress curve (AUDPC) which was estimated as per the equation suggested by Shaner and Finnay (1977) as- 
AUDPC $=\sum_{i=1}^{n}\left(\frac{y_{i}+y_{i+1}}{2}\right)\left(t_{i+1}-t_{i}\right)$

In which

$\mathrm{n}=$ total number of observations

$\mathrm{y}_{\mathrm{i}}=$ disease severity at the $\mathrm{i}^{\text {th }}$ observation

$\mathrm{t}=$ time at the $\mathrm{i}^{\text {th }}$ observation

\section{Calculation of correlation coefficient}

The progression of the diseases was analyzed with prevailing weather variables such as temperature (Tmax and Tmin), rainfall (RF), relative humidity (RHm and $\mathrm{RHe}$ ) and sunshine hours (SSH).

The correlation coefficients between various weather parameters and sheath blight disease severity were calculated. Correlation coefficient measures the severity strength of the linear relationship between two variables $\mathrm{X}$ and $\mathrm{Y}$ ( $\mathrm{Y}$ is the disease severity and $\mathrm{X}$ is the different weather parameters). It is calculated by using following formula-

$$
\mathbf{r}=\frac{\Sigma(\mathrm{x}-\overline{\mathrm{x}})(\mathrm{y}-\overline{\mathrm{y}})}{\sqrt{\left[\Sigma(\mathrm{x}-\overline{\mathrm{x}})^{2}(\mathrm{y}-\overline{\mathrm{y}})^{2}\right]}}
$$

\section{Results and Discussion}

During disease development, trend and its relation to weather variables were analyzed in three staggering dates of sowing, pooled as well as year wise to validate the previous years' data with the data collected during kharif 2016.

\section{Disease development}

In the year 2013, sheath blight disease development during first date of sowing varied from 5.04 to $30.04 \%$ and 4.77 to $29.39 \%$ and 11.37 to $32.53 \%$ during second and third date of sowing, respectively.
Sheath blight disease development in the year 2014 varied in all three dates of sowing. During first date of sowing, it ranges from 20.78 to $82.20 \%$. During second date of sowing, it was 4.21 to $44.13 \%$ and 1.91 to $37.64 \%$ in third date of sowing.

In the year 2015, sheath blight disease development varied from 7.35 to $45.51 \%$, 7.08 to $34.73 \%$ and 5.5 to $41.73 \%$ during first, second and third date of sowing, respectively.

The data presented in Table 1 reveal that the disease development during first date of sowing in kharif 2016 was varied from 5.63 to $80.57 \%$. In second and third date of sowing, it was 5.31 to $60.33 \%$ and 5.20 to $50.17 \%$, respectively.

\section{Disease progression}

As far as the sheath blight disease progression was concerned, irrespective of dates of sowing the maximum progression $(13.76 \%)$ was observed during 16-30 October in kharif 2013. The progression of disease was ranges between 0.05 to $13.11 \%$ in the first date of sowing with maximum $13.11 \%$ during $1-15$ October, 2013. During second date of sowing, it was ranges from 0.12 to $11.69 \%$ with maximum 11.69\% during 1-15 October, 2013. Disease progression in third date of sowing ranges from 7.4 to $13.76 \%$ with intermediate of $11.37 \%$ during 1-15 October, 2013. So, it was appeared that sheath blight progression was almost maximum during 1-15 October in kharif 2013. During this period, average Tmax was $30.6^{\circ} \mathrm{C}$, Tmin $24.9^{\circ} \mathrm{C}$, RHm 92.6\%, RHe $73.7 \%$, RF $5.5 \mathrm{~mm}$ and SSH 4.4.

In the kharif 2014, maximum disease progression $28.14 \%$ was observed during 115 November irrespective of dates of sowing. Disease progression ranges between 0.77 to $28.14 \%$ in the first date of sowing. During second date of sowing, it was varied from 
0.63 to $17.54 \%$ with maximum of $17.54 \%$ during 16-30 October, 2014. In third date of sowing, it ranges between $1.91-14.96 \%$ with maximum of $14.96 \%$ during 1-15 October, 2014. It appeared that period from 01 October to 15 November was favourable for maximum sheath blight progression during kharif 2014. During this period, fortnightly average Tmax ranges from 32.6 to $32.8^{\circ} \mathrm{C}$, Tmin 14.82 to $21.0^{\circ} \mathrm{C}, \mathrm{RHm} 87.8$ to $91.1 \%$, RHe 30.46 to $54.6 \%$ and SSH 7.56 to 8.13 .

Maximum sheath blight disease progression was observed $14.02 \%$ irrespective of dates of sowing. Disease progression was ranges from 2.53 to $10.11 \%$ in first date of sowing with maximum $10.11 \%$ during 16-30 October, 2015. During this period, maximum disease progression was observed i.e. $8.81 \%$ in second date of sowing and it ranges between 2.87 to $8.81 \%$. In third date of sowing, it varied between 5.05 to $14.02 \%$ with maximum $14.02 \%$ during 1-15 October. It appeared that period from 1-30 October was favourable for maximum sheath blight progression during kharif 2015. During this period, fortnightly Tmax ranges from 31.9 to $32.4^{\circ} \mathrm{C}$, Tmin 24.8 to $25.5^{\circ} \mathrm{C}$, RHm 92.8to $93.7 \%$, RHe 64.2 to $69.5 \%$, RF 1.5 to 13.6 $\mathrm{mm}$ and SSH 5.7 to 8.2 .

During kharif 2016, maximum sheath blight disease progression was recorded as $20.15 \%$ irrespective of dates of sowing. In first date of sowing, it ranges from 5.63 to $20.15 \%$ with maximum 20.15\% during 1-15 October followed by 19.87 during 16-30 October. It was varied from 5.31 to $17.63 \%$ during second date of sowing with the maximum of $17.63 \%$ during 1-15 October. In third date of sowing, it ranges between 5.20 to $13.84 \%$ with maximum of $13.84 \%$ during 1-15 October, 2016. During kharif 2016, it appeared that period from 1 to 15 October favours the sheath blight disease progression irrespective of dates of sowing. During this period, fortnightly Tmax was $31.2^{\circ} \mathrm{C}$, Tmin $24.8^{\circ} \mathrm{C}$, RHm $94.7 \%$, RHe $63.2 \%$ and $\mathrm{SSH}$ 4.9 (Table 2).

\section{Apparent infection rate (r)}

The apparent infection rate (r) for sheath blight disease development was calculated and presented in Table 3. During kharif 2013, maximum $\mathrm{r}$ value 0.095 was recorded in between 16-30 September to 1-15 October in first date of sowing, in second date of sowing 0.090 and 0.064 in third date of sowing in between 1-15 October to 16-30 October.

Apparent infection rate was maximum 0.091 in between 16-30 October and 1-15 November in first date of sowing during kharif 2014. In second date of sowing, it was maximum 0.107 in between 1-15 October and 16-30 October and 0.56 in between 16-30 September 1-15 October in third date of sowing.

Maximum $\mathrm{r}$ value calculated as 0.029 in between 1-15 October and 16-30 October in first date of sowing during kharif 2015. In second date of sowing, it was maximum 0.037 and in third date of sowing, maximum $r$ value was 0.068 in between 16-30 September to 115 October.

During kharif 2016, apparent infection rate was maximum 0.057 in between 16-30 September and 1-15 October in first date of sowing, 0.053 in second date of sowing and 0.102 in third date of sowing.

In the present study, sheath blight disease progression and apparent infection rate (r) were maximum during observation period from 1-15 and 16-30 October in over the four years kharif season. At this time, the variety Swarna was in between maximum tillering and panicle initiation stage. Findings of several other workers support the findings of 
present study (Viswanathan 1979; Roy 1984 and 1986; Dath, 1989; Sarkar et al., 1993; Tan et al., 1995; Lakpale et al., 1996; Tiwari and Choure, 1997; Zhang et al., 1999; Biswas, 2001 panicle initiation; Thind, 2008).

Whereas some other workers were found different growth stages susceptible for infection. Shahjahan et al., (1990) reported panicle initiation to booting; Chang and Dath (1996) flowering; $\mathrm{Cu}$ et al., (1996) panicle initiation, flowering and booting; Vanitha et al., (1996) found booting and flowering stage; Sharma and Teng (1996) flowering and panicle initiation stage; Munshi and Singh (2000) flowering and Pal et al., (2016) found grain filling stage as most susceptible for sheath blight disease to occur.

Table.1 Sheath blight disease severity in four years kharif season (2013-2016)

\begin{tabular}{|c|c|c|c|c|}
\hline \multirow[b]{2}{*}{ Year } & \multirow{2}{*}{ Observation period } & \multicolumn{3}{|c|}{ Disease severity (\%) } \\
\hline & & $1^{\text {st }}$ DOS & $2^{\text {nd }}$ DOS & $3^{\text {rd }}$ DOS \\
\hline \multirow{10}{*}{2013} & 01-15 August & 0.00 & 0.00 & 0.00 \\
\hline & 16-30 August & 0.00 & 0.00 & 0.00 \\
\hline & 01-15 September & 5.04 & 4.77 & 0.00 \\
\hline & 16-30 September & 5.09 & 4.89 & 0.00 \\
\hline & 01-15 October & 18.20 & 16.58 & 11.37 \\
\hline & 16-30 October & 23.02 & 21.85 & 25.13 \\
\hline & 01-15 November & 30.04 & 29.39 & 32.53 \\
\hline & 01-15 August & 20.78 & 0.00 & 0.00 \\
\hline & 16-30 August & 29.37 & 4.21 & 0.00 \\
\hline & 01-15 September & 30.14 & 4.84 & 1.91 \\
\hline \multirow{7}{*}{2014} & 16-30 September & 34.56 & 20.22 & 16.87 \\
\hline & 01-15 October & 37.97 & 25.74 & 23.61 \\
\hline & 16-30 October & 54.06 & 43.28 & 33.15 \\
\hline & 01-15 November & 82.2 & 44.13 & 36.13 \\
\hline & 16-30 November & 0.00 & 0.00 & 37.64 \\
\hline & 01-15 August & 7.35 & 0.00 & 0.00 \\
\hline & 16-30 August & 17.01 & 7.08 & 0.00 \\
\hline \multirow[t]{8}{*}{2015} & 01-15 September & 21.37 & 11.68 & 5.5 \\
\hline & 16-30 September & 25.28 & 14.55 & 10.55 \\
\hline & 01-15 October & 32.87 & 18.39 & 24.57 \\
\hline & 16-30 October & 42.98 & 27.2 & 34.2 \\
\hline & 01-15 November & 45.51 & 34.73 & 41.73 \\
\hline & 01-15 August & 5.63 & 0.00 & 0.00 \\
\hline & 16-30 August & 15.12 & 5.31 & 5.20 \\
\hline & 01-15 September & 20.71 & 15.08 & 16.52 \\
\hline \multirow[t]{4}{*}{2016} & 16-30 September & 30.08 & 25.90 & 26.74 \\
\hline & 01-15 October & 50.23 & 43.53 & 40.63 \\
\hline & 16-30 October & 70.10 & 50.79 & 50.17 \\
\hline & 01-15 November & 80.57 & 60.33 & 0.00 \\
\hline
\end{tabular}


Table.2 Fortnightly disease progression (\%) of sheath blight during four years kharif season (2013-2016)

\begin{tabular}{|c|c|c|c|c|c|c|c|c|c|c|c|c|}
\hline \multirow[b]{2}{*}{$\begin{array}{l}\text { Observation } \\
\text { period }\end{array}$} & \multicolumn{3}{|c|}{2013} & \multicolumn{3}{|c|}{2014} & \multicolumn{3}{|c|}{2015} & \multicolumn{3}{|c|}{2016} \\
\hline & $\begin{array}{c}1^{\text {st }} \\
\text { DOS }\end{array}$ & $\begin{array}{c}2^{\text {nd }} \\
\text { DOS }\end{array}$ & $\begin{array}{c}3^{\mathrm{rd}} \\
\text { DOS }\end{array}$ & $1^{\text {st }}$ DOS & $\begin{array}{c}2^{\text {nd }} \\
\text { DOS }\end{array}$ & $\begin{array}{c}3^{\text {rd }} \\
\text { DOS }\end{array}$ & $1^{\text {st }} \mathrm{DOS}$ & $\begin{array}{c}2^{\text {nd }} \\
\text { DOS }\end{array}$ & $\begin{array}{c}3^{\text {rd }} \\
\text { DOS }\end{array}$ & $1^{\text {st }} \mathrm{DOS}$ & $\begin{array}{c}2^{\text {nd }} \\
\text { DOS }\end{array}$ & $\begin{array}{c}3^{\text {rd }} \\
\text { DOS }\end{array}$ \\
\hline 16-30 July & 0 & 0 & 0 & 0 & 0 & 0 & 0 & 0 & 0 & 0 & 0 & 0 \\
\hline 01-15 August & 0 & 0 & 0 & 20.78 & 0 & 0 & 7.35 & 0 & 0 & 5.63 & 0 & 0 \\
\hline 16-30 August & 0 & 0 & 0 & 8.59 & 4.21 & 0 & 9.66 & 7.08 & 0 & 9.49 & 5.31 & 5.2 \\
\hline 01-15 September & 5.04 & 4.77 & 0 & 0.77 & 0.63 & 0 & 4.36 & 4.6 & 5.5 & 5.59 & 9.77 & 11.32 \\
\hline 16-30 September & 0.05 & 0.12 & 0 & 4.42 & 15.38 & 1.91 & 3.91 & 2.87 & 5.05 & 9.37 & 10.82 & 10.27 \\
\hline 01-15 October & 13.11 & 11.69 & 11.37 & 3.41 & 5.52 & 14.96 & 7.59 & 3.84 & 14.02 & 20.15 & 17.63 & 13.84 \\
\hline 16-30 October & 4.82 & 5.27 & 13.76 & 16.09 & 17.54 & 6.74 & 10.11 & 8.81 & 9.63 & 19.87 & 7.26 & 9.54 \\
\hline 01-15 November & 7.02 & 7.54 & 7.4 & 28.14 & 0.85 & 9.54 & 2.53 & 7.53 & 7.53 & 10.47 & 9.54 & 9.54 \\
\hline 16-30 November & & & & & & 2.98 & & & & & & \\
\hline
\end{tabular}

Table.3 Apparent infection rate (r) of sheath blight disease development during four years kharif season (2013-2016)

\begin{tabular}{|c|c|c|c|c|c|c|c|c|c|c|c|c|}
\hline \multirow{2}{*}{$\begin{array}{l}\text { Observation } \\
\text { period }\end{array}$} & \multicolumn{3}{|c|}{2013} & \multicolumn{3}{|c|}{2014} & \multicolumn{3}{|c|}{2015} & \multicolumn{3}{|c|}{2016} \\
\hline & $\begin{array}{c}1^{\text {st }} \\
\text { DOS }\end{array}$ & $\begin{array}{c}2^{\text {nd }} \\
\text { DOS }\end{array}$ & $\begin{array}{c}3^{\text {rd }} \\
\text { DOS }\end{array}$ & $\begin{array}{c}1^{\text {st }} \\
\text { DOS }\end{array}$ & $\begin{array}{c}2^{\text {nd }} \\
\text { DOS }\end{array}$ & $\begin{array}{c}3^{\text {rd }} \\
\text { DOS }\end{array}$ & $\begin{array}{c}1^{\text {st }} \\
\text { DOS }\end{array}$ & $\begin{array}{c}2^{\text {nd }} \\
\text { DOS }\end{array}$ & $\begin{array}{c}3^{\text {rd }} \\
\text { DOS }\end{array}$ & $\begin{array}{c}1^{\text {st }} \\
\text { DOS }\end{array}$ & $\begin{array}{c}2^{\text {nd }} \\
\text { DOS }\end{array}$ & $\begin{array}{c}3^{\text {rd }} \\
\text { DOS }\end{array}$ \\
\hline 16-30 July & 0 & 0 & 0 & 0 & 0 & 0 & 0 & 0 & 0 & 0 & 0 & 0 \\
\hline 01-15 August & 0 & 0 & 0 & 0.031 & 0 & 0 & 0.020 & 0 & 0 & 0.032 & 0 & 0 \\
\hline 16-30 August & 0 & 0 & 0 & 0.002 & 0.010 & 0 & 0.019 & 0.034 & 0 & 0.033 & 0.027 & 0 \\
\hline 01-15 Sept. & 0.001 & 0.002 & 0 & 0.013 & 0.053 & 0 & 0.015 & 0.017 & 0.047 & 0.026 & 0.045 & 0 \\
\hline 16-30 Sept. & 0.095 & 0.090 & 0.0 & 0.010 & 0.021 & 0.56 & 0.025 & 0.019 & 0.031 & 0.057 & 0.053 & 0.102 \\
\hline 01-15 October & 0.020 & 0.023 & 0.064 & 0.044 & 0.107 & 0.028 & 0.29 & $\mathbf{0 . 0 3 7}$ & 0.068 & 0.056 & 0.019 & 0.036 \\
\hline 16-30 October & 0.024 & 0.027 & 0.024 & 0.091 & 0.002 & 0.032 & 0.007 & 0.024 & 0.021 & 0.053 & 0.026 & 0.030 \\
\hline 01-15 November & 0 & 0 & 0 & 0 & 0 & 0.009 & 0 & 0 & 0 & 0.036 & 0 & 0.026 \\
\hline 16-30 November & 0 & 0 & 0 & 0 & 0 & 0.004 & 0 & 0 & 0 & 0 & 0 & 0 \\
\hline
\end{tabular}


Table.4 Value of area under disease progress curve (AUDPC) in four years kharif season (2013-2016)

\begin{tabular}{cccc}
\hline Year & DOS & Sheath Blight & Rank \\
\hline \multirow{2}{*}{2013} & $1^{\text {st }}$ DOS & 1220.85 & I \\
& $2^{\text {nd }}$ DOS & 1162.20 & II \\
& $3^{\text {rd } D O S ~}$ & 1035.45 & III \\
& $1^{\text {st } D O S ~}$ & 4336.2 & I \\
& $2^{\text {nd }}$ DOS & 2136.3 & III \\
& $3^{\text {rd }}$ DOS & 2239.65 & II \\
& $1^{\text {st }}$ DOS & 2885.55 & I \\
& $2^{\text {nd }}$ DOS & 1748.25 & II \\
& $3^{\text {rd }}$ DOS & 1704.45 & III \\
& $1^{\text {st }}$ DOS & 4131.60 & I \\
& $2^{\text {nd }}$ DOS & 3014.10 & II \\
& $3^{\text {rd }}$ DOS & 2198.25 & III \\
\hline
\end{tabular}

Table.5 Year wise correlation coefficient between weather parameters and sheath blight disease severity over four years kharif season (2013-2016)

\begin{tabular}{|c|c|c|c|c|c|c|c|}
\hline DOS & r-value & $\operatorname{Tmax}^{0} \mathrm{C}$ & $\operatorname{Tmin}^{0} \mathrm{C}$ & $\operatorname{RHm}(\%)$ & RHe(\%) & R.F. (mm) & S.S.(Hr) \\
\hline \multicolumn{8}{|c|}{2013} \\
\hline $\mathrm{I}^{\mathrm{st}} \mathrm{DOS}$ & $r=0.950$ & -0.27 & -0.65 & -0.88 & -0.66 & -0.49 & 0.36 \\
\hline II $^{\text {nd }}$ DOS & $\mathrm{r}=0.878$ & 0.36 & $-0.89 *$ & -0.43 & -0.82 & $-0.89 *$ & 0.71 \\
\hline $\mathrm{III}^{\mathrm{rd}} \mathrm{DOS}$ & $r=0.950$ & 0.25 & -0.94 & -0.59 & -0.90 & $-1.00 *$ & 0.85 \\
\hline \multicolumn{8}{|c|}{2014} \\
\hline$I^{\text {st }}$ DOS & $r=0.754$ & 0.62 & $-0.95^{*}$ & $-0.90 *$ & $-0.94 *$ & -0.68 & $0.77 *$ \\
\hline II $^{\text {nd }}$ DOS & $r=0.811$ & 0.64 & $-0.94 *$ & $-0.90 *$ & $-0.97 *$ & $-0.82 *$ & $0.89 *$ \\
\hline $\mathrm{III}^{\mathrm{rd}} \mathrm{DOS}$ & $r=0.811$ & $0.84 *$ & $-0.91 *$ & $-0.92 *$ & $-0.95 *$ & $-0.94 *$ & $0.97 *$ \\
\hline \multicolumn{8}{|c|}{2015} \\
\hline$I^{\text {st }}$ DOS & $r=0.754$ & 0.37 & -0.53 & 0.40 & -0.67 & -0.48 & $0.91 *$ \\
\hline II $^{\text {nd }}$ DOS & $\mathrm{r}=0.811$ & 0.06 & -0.74 & -0.22 & -0.77 & -0.51 & $0.85 *$ \\
\hline $\mathrm{III}^{\mathrm{rd}} \mathrm{DOS}$ & $r=0.878$ & 0.10 & -0.67 & 0.03 & -0.51 & -0.44 & $0.89 *$ \\
\hline \multicolumn{8}{|c|}{2016} \\
\hline $\mathrm{I}^{\mathrm{st}} \mathrm{DOS}$ & $r=0.754$ & 0.37 & $-0.85^{*}$ & -0.33 & $-0.94 *$ & -0.66 & $0.92 *$ \\
\hline II $^{\text {nd }}$ DOS & $r=0.811$ & 0.11 & $-0.86^{*}$ & -0.29 & $-0.85^{*}$ & -0.51 & $0.82 *$ \\
\hline $\mathrm{III}^{\mathrm{rd}} \mathrm{DOS}$ & $r=0.878$ & 0.79 & $-0.96 *$ & -0.85 & $-0.91 *$ & -0.66 & 0.66 \\
\hline
\end{tabular}

\section{Area under disease progress curve}

The data presented in Table 4 regarding area under disease progress curve (AUDPC) revealed that maximum AUDPC value 1220.85 was calculated in first date of sowing followed by 1162.2 in second date of sowing and 1035.45 in third date of sowing during kharif 2013. During kharif 2014, maximum AUDPC value 4336.2 was calculated in first date of sowing followed by 2239.65 in third date of sowing and 2136.3 in second date of sowing.

During kharif 2015, AUDPC value 2885.55 was calculated in first date of sowing 
followed by 1748.25 in second date of sowing and 1704.45 in third date of sowing.

The trend was similar in kharif 2016, the maximum AUDPC value was calculated in first date of sowing 4131.6 followed by 3014.1 in second date of sowing and 2198.25 in third date of sowing.

In all the maximum value of AUDPC calculated in first date of sowing followed by second date of sowing and least in third date of sowing during kharif 2013, 2015 and 2016. In kharif 2014, it was maximum in first date of sowing followed by third date of sowing and least in second date of sowing.

The above results clearly indicate that early sowing of paddy favours sheath blight disease development.

This finding was in agreement with finding of Hori, 1984; Chang et al., 1985; Kaur et al., 2015; Bhukal et al., 2015 and Pal et al., 2016 as they also reported early sowing favours the sheath blight disease development.

\section{Correlation analysis}

Correlation between weather parameters and sheath blight disease severity was calculated year wise also from 2013 to 2016 in all three date of sowing individually and data presented in Table 5.

\section{$\operatorname{Tmax}$}

In kharif 2013, correlation between Tmax with sheath blight disease severity was positive in second and third date of sowing whereas it was negative in first date of sowing. During kharif 2014, correlation was positive in all three dates of sowing and significant in third date of sowing. In kharif 2015 , correlation was positive in all three date of sowing.
Similarly in kharif 2016, correlation was positive in all three date of sowing which was almost confers that Tmax had positive effect for the development of sheath blight of rice in previous three years kharif season.

\section{Tmin, RHm, RHe and RF}

Correlation between Tmin, RHm, RHe, RF and sheath blight disease severity reveal that correlation was negative in all three date of sowing in all kharif seasons of 2013-2016.

\section{SSH}

Correlation between SSH and sheath blight severity was positive in all three dates of sowing in the kharif season of 2013-2016 which was significant in all three dates of sowing in kharif 2014-2016 and all three date of sowing in kharif 2014-2015 and first and second date of sowing in kharif 2016. From the above, it appears that SSH had direct effect on sheath blight development during kharif season of 2013-16.

Year wise correlation analysis between weather parameters and sheath blight disease severity suggest that Tmax and SSH had positive effect in the development of sheath blight disease of rice during kharif season. During the period from 16 September to 30 October in kharif season of 2013-16, crop growth stage was in maximum tillering to panicle initiation stage coincide with the Tmax range $\left(30.5-32.6^{\circ} \mathrm{C}\right)$ and $\mathrm{SSH}$ range (4.2-9.6) which favours the maximum apparent rate of infection by Rhizoctonia solani and resulted in maximum sheath blight disease progression (Table 2 and 3 ).

Findings of earlier researchers are in close proximity of findings of present study. Nandi and Chakrabarti (1977) reported mean weekly temperature 23.1 to $33.9^{\circ} \mathrm{C}$ and mean relative humidity 65-93 \%; Yuno et al., (1978) 
maximum and minimum temperature and rate of evaporation; Hashiba et al., (1982) temperature $28^{\circ} \mathrm{C}$, RH $100 \%$ continuous low RF; Gangopadhyay (1983) and $\mathrm{Ou}$ (1985) temperature $30-32^{\circ} \mathrm{C}$ and $\mathrm{RH}$ 81-92\%; Kataria and Grover (1987); Tsai et al., (1994) accumulated solar radiation; Castilla et al., (1996) maximum air temperature and RHm; Tiwari (1997) $30^{\circ} \mathrm{C}$ for Sclerotia formation; Singh (1998) temperature $30-32^{\circ} \mathrm{C}$ and $\mathrm{RH}$ 96-97\%; Sarkar et al., (2000) high temperature; Rangaswami and Mahadevan (2005) high humidity and warm temperature; Wrather et al., (2007) humidity 96-97\%; Thind et al., (2008) temperature $25-30^{\circ} \mathrm{C}$ and RH 80-100 \%; Biswas et al., (2011) maximum air temperature $34^{\circ} \mathrm{C}$ and $\mathrm{RHm}$ more than $90 \%$; Dutta and Kalha (2011) temperature $30^{\circ} \mathrm{C}$ and $\mathrm{RH}>90 \%$; Henry and Devasahayam (2011) RH 96-97\% and temperature $30-32^{\circ} \mathrm{C}$; Bhukal et al., (2015) temperature $31-33^{\circ} \mathrm{C}, \mathrm{RHm}$ and $\mathrm{RHe}>90 \%$; Singh et al., (2016) $\mathrm{RH}>80 \%$ and $28^{\circ} \mathrm{C}$ temperature; Pal et al., (2016) maximum temperature $31-34^{\circ} \mathrm{C}$ favours the development of sheath blight disease. On the contrary, Mathai et al., (1986) found maximum temperature was non-significant and Reddy et al., (2001) reported temperature and sunshine negatively correlated with sheath blight disease.

In the present study, minimum temperature, RHe and rainfall were negatively correlated with sheath blight disease severity. But some other workers found that the above weather parameters were conducive for disease development. Yuno et al., (1978) reported minimum temperature; Mathai et al., (1986) minimum temperature; Savary et al., (2001) rainfall; Lenka et al., (2008) minimum temperature and evaporation rate; Dutta and Kalha (2011) high and frequent rains; Bhukal et al., (2015) minimum temperature; Kaur et al., (2015) minimum temperature, evening relative humidity and rainfall and Singh et al.,
(2015) found rainfall favoured the sheath blight disease development.

\section{Acknowledgements}

This manuscript is the part of M.Sc. (Ag) thesis work. Hence, the authors would like to thank the Department of Plant Pathology, College of Agriculture, Indira Gandhi Krishi Vishwavidyalaya, Raipur, Chhattisgarh for the technical support.

\section{References}

Anonymous 2016. Krishi darshika, DES, IGKV, Raipur(C.G).pp 5.

Bhukal, N., Singh, R. and Mehta, N. 2015. Progression and development of sheath blight of rice in relation to weather variables. J. Mycol. Plant Pathol., 45(2): 166-172.

Biswas, B., Dhaliwal, L.K., Chahal, S.K. and Pannu P.P.S. 2011. Effect of meteorological factors on rice sheath blight and exploratory development of a predictive model. Indian Journal of Agricultural Science, 81(3): 256-260.

Castilla, N.P., Leano, R.M., Elazegui, F.A., Teng, P.S. and Savary, S. 1996. Effects of plant contact inoculation pattern, leaf wetness regime and nitrogen supply on the efficiency in rice sheath blight. J. Phytopathol., 144: 187-192.

Chang S.J. and Premalatha Dath. 1996. Effect of the growth stage of rice plant on the severity of sheath blight as assessed by different parameter. Oryza, 33: 149152.

Chang, Y.C. 1985. Studies on the effect of disease severity of sheath blight on rice yield. J. agric. Res. China, 35: 202-209.

$\mathrm{Cu}$, R.M., Mew, T.W., Cassman, K.G. and Teng, P. S. 1996. Effect of sheath blight on yield in tropical, intensive rice production system. Plant Disease, 80: 1103-1108. 
Dath, P.A. 1989. Sheath Blight of Rice and its Management. Associated Publishing Co., Shidipura, Karol Bagh, New Delhi, 129.

Dutta, U. and Kalha, C.S. 2011.Effect of meteorological parameters on development of sheath blight disease in Paddy. Pl. Dis. Res., 26 (2):122-126.

Gangopadhyay, S. 1983. Current Concepts on Fungal Diseases of Rice. Today and Tomorrow, New Delhi.

Hashiba, T. 1982. Forecasting and estimation of yield losses by rice sheath blight disease. Journal of Agricultural Research, 18: 92-98.

Henry, L.D.C. and Devasahayam, T.H.L. 2011. Crop Diseases: Identification, Treatment and Management. New India Publishing Agency Pitam Pura, New Delhi, 1-27.

Hori, M. 1984. Present status of occurrence and chemical control of sheath blight in Japan. Japan Pesticide Information, 44: 6-10.

Katariya, H.R. and Grower, R.K.1987. Some factors affecting the control of Rhizoctonia solani by systemic and non systemic fungicides. Ann. Appl. Biol., 82: 267-271.

Kaur, A., Dhaliwal, L.K. and Pannu, P.P.S. 2015.Role of Meteorological Parameters on Sheath Blight of Rice under different Planting Methods. International Journal of Bio-resource and Stress Management, 6 (2): 214-219.

Lakpale, N., Kotasthane, A.S., Thrimurty, V.S., Agrawal, K.C. 1996. Influence of host factors on sheath blight of rice. Indian Journal of Mycology and Plant Pathology 26: 193-195.

Lenka, S., Mishra, S.K., Mohanty., S.K. and Saha, S. 2008. Role of weather parameters on sheath blight incidence in rice caused by Rhizoctonia solani Kuhn. Oryza, 45(4): 336-338.

Mathai, G., Santhakumari, P., Ramadevi, L. and Krishnakumari, A.P.R. 1986. Influence of weather on sheath blight and sheath rot disease of rice. Indian J. Pl. Pro., 14: 7-9.

Munshi, G.D. and Singh, M. 2000. Development of sheath blight of rice in relation to plant growth stages. Pl. Dis. Res., 15: 182-85.

Nandi, S. and Chakrabarti, N.K. 1977. Annual Report, Central Rice Research Institute, Cuttack. pp. 80-85.

Ou, S.H. 1985. Rice Diseases. $2^{\text {nd }}$ Edition. CMI., Kew, Surrey, U.K., 272-286.

Pal, R., Mandal, D. and Biswas, M.K. 2016. Effect of different sowing dates on the development and spread of sheath blight disease in rice. Journal of Crop and Weed, 12(1):116-119.

Rangaswami, G. and Mahadevan, A. 2005. Diseases of Crop Plants in India. $4^{\text {th }}$ Edition. Prentice-Hall of India Private Limited, New Delhi, 169-179.

Reddy, M.M., Reddy, C.S. and Reddy, A.G.R. 2001. Influence of weather parameters and insect pest populations on incidence and development of sheath rot of rice. Indian Phytopath., 54(2): 179-184.

Roy, A.K. 1984. Survival of Corticium sasakii in upland soil of Assam. Oryza, 21: 173-175.

Roy, A.K. 1986. Survival of sclerotia of Rhizoctonia solani f. sp. Sasakii in relation to moisture regime of soil. Ind. Phytopath., 39(2): 259-263.

Sarkar, M.K., Basu, A. and Sengupta, P.K. 1993. Effect of host growth stage. Leaf sheath position and sheath injury on severity of rice sheath blight. Indian phytopath., 25: 210-214.

Sarkar, M.K., Sharma, B.D. and Sengupta, P.K. (2000). Pathotypes in rice sheath blight organism, Rhizoctonia solani. Annals of Plant Protection Science, 8: 109-111.

Savary, A Castilla, N.P. and Willocquet, L. 
2001. Analysis of the spatiotemporal structure of rice sheath blight epidemics in a farmer's field. Plant Pathology, 50(1): 53.

Shahjahan, A.K.M., Ahmed, H.U., Sharma, N.R. and Miah, S.A. 1990. Epidemiological studies of sheath blight of rice caused by Rhizoctonia solani Kuhn (in Bangladesh).Bangladesh Agricultural Research Council.

Shaner, G. and Finney, R.E. 1977. The effect of nitrogen fertilisation on the expression of slow-mildewing resistance in Knox wheat. Phytopathology, 67:1051-1056.

Sharma, N.R. and Teng, P.S. 1996. Rice sheath blight: Effect of crop growth stage on sheath blight disease development and yield loss. IRRI, News Letter, 15 (6): 19-20.

Singh, R., Sunder, S. and Kumar, P. 2016. Sheath blight of rice: current status and perspectives. Indian Phytopath, 69 (4): 340-351.

Singh, R.S. (1998). Plant diseases. $7^{\text {th }}$ Edition, Oxford and IBH Publishing Co. Pvt. Ltd., New Delhi, 63-68.

Tan-Li, Tan, G.J., Ji, B.H. and Yao, L. 1995. A quantitative study on the controlling effect of Jinggamycin to rice sheath blight. Plant Protection, 21: 5-7.

Thind, T.S., Mohan, C., Sharma, V.K., Raj, P., Arora, J.K. and Singh, P.P. 2008. Functional relationship of sheath blight of rice with crop age and weather factors. Plant Disease Research, 23(1): 34-40.

Tiwari, R.K.S. 1997. Assessment of losses in yield components in relation to sheath blight of rice. J. Mycol. Pl. Pathol., 27: 44-47.

Tiwari, R.K.S. and Chaure, N.K. 1997. Studies on factors influencing appearance and severity of sheath blight (Rhizoctonia solani f. sp. sasakii) of rice. Advances in plant science, 10: 223-226.

Tsai, W.H. 1974. Assessment of yield losses due to rice sheath blight at different inoculation stages. Journal of Taiwan Agricultural Research, 23: 188-194.

Vander Plank J.E. 1963. Plant diseases epidemics and control.Academic Press, London, 249.

Vanitha, S., Thangamani, G. and Narayanaswamy. 1996. Influence of age and infection in relation to sheath blight susceptibility in rice. J. Madras Agric., 83: 63-64.

Viswanathan, V. 1979. Annual Report. All India Coordinated Rice Improvement Project.

Wrather, A., Beck, D., Guethle, B., Cartwright, R. 2007. Rice sheath blight control. University of Missouri-Delta Center.

Yuno, L., Hashiba, T. and Mogi, S. 1978. Effect of temperature on disease development of rice sheath blight caused by $R$. solani. Proceedings Assoc. Plant., 26: 4-9.

Zhang, Y.G., Miao, R.G. and Huang, Y.F. 1999. Occurrence and control of sheath blight disease in casting seedling fields. Pl. Protec., 25(3): 18-20.

\section{How to cite this article:}

Leena Thakur, N. Lakpale, P.K. Tiwari and Ashish Pradhan. 2017. Epidemiological Studies on Sheath Blight Disease of Rice in Chhattisgarh Plains Agroclimatic Zone of Chhattisgarh, India. Int.J.Curr.Microbiol.App.Sci. 6(11): 1351-1361. doi: https://doi.org/10.20546/ijcmas.2017.611.161 